\title{
Rabies virus litter-to-mother vertical transmission, a phenomenon that could preserve the virus in wildlife reservoirs
}

Nidia Aréchiga-Ceballos, ${ }^{1}$ Cenia Almazán-Marín² and Álvaro Aguilar-Setién²*

${ }^{1}$ Secretaría de Salud, Institute of Epidemiological Diagnosis and Reference, Department of Virology, Rabies Laboratory; ${ }^{2}$ Instituto Mexicano del Seguro Social, Coordination of Medical Research, Medical Research Unit in Immunology. Ciudad de México, Mexico

\begin{abstract}
Introduction: The biological test established by the World Health Organization to isolate and amplify the rabies virus consists in inoculating lactating mice by intracranial route and detecting rabies signs for 21 days. Objective: To verify viral transmission in mothers of rabies virus-inoculated lactating mice. Method: Twenty-seven Mexican rabies virus isolates were inoculated by intracranial route in lactating mice, which were observed for 21 days. The mothers were observed for 60 days. The diagnosis was established by immunofluorescence in brain tissue. The virus was characterized by sequencing and with monoclonal antibodies. Results: All litters showed rabies at between 7 and 15 days post-inoculation (p.i.). Three of the 27 females (11 \%) had developed rabies at days 33, 37 and 39 p.i. of their litters. Viral characterization showed that the mothers were infected with the same variant of their offspring, two of them stemming from hematophagous bat and one from dog. The litters that transmitted rabies to their mothers were nine individuals. Conclusions: In nature, the rabies virus could be preserved by transmission from neonates (more susceptible to contracting and amplifying the rabies virus) to their mothers.
\end{abstract}

KEY WORDS: Rabies virus. Litter-to-mother vertical transmission. Biological tests.

\section{Introduction}

The mouse inoculation test (MIT) is the standard biological test for rabies recommended since long time ago by the World Health Organization consisting in isolation and amplification of the virus by inoculating litters of mice of about three days from being born. ${ }^{1}$ The use of breastfed animals was established due to their higher susceptibility, since their immune system is not fully developed.

Currently, for animals welfare, international organizations have recommended gradually abandoning the use mice and restrict research activities to the use of cell cultures. However the MIT is still common practice, since in addition to isolating and increasing viral titers, it allows reproducing Koch's postulates.

In Mexico, canine rabies vaccination campaigns have been successful and, since 2005, no cases of dog-transmitted human rabies have been recorded. From 2000 to 2018, there were 52 cases of human rabies, out of which $48(92 \%)$ were transmitted by wild animals (mainly chiropters and mustelids) and only four (8\%) by dogs (Institute of Epidemiological Diagnosis and Reference, unpublished data). This makes necessary to continue studying the permanence and dissemination of Rabies Virus (RV). In wildlife, intra- and interspecies fights, community grooming, sharing food by regurgitation and the secretion of aerosols appear to be routes of dissemination for the virus.

The purpose of this investigation was to verify whether litter-to-mother contagion could be a means of viral spread when performing the MIT with several samples of a historical bank, for which purpose the period of maternal observation was extended (to up to 60 days).
Correspondence:

*José Álvaro Aguilar-Setién

E-mail: balantiopterix@gmail.com
Date of reception: 20-01-2019

Date of acceptance: 21-02-2019

DOI: 10.24875/GMM.M19000266
Gac Med Mex. 2019;155:228-232

Contents available at PubMed www.gacetamedicademexico.com 


\section{Method}

Tests were made using $27 \mathrm{RV}$ samples from different places in Mexico and different species (Table 1).

Four to seven-day-old BALB/C mouse litters were inoculated, one litter per sample $(n=27)$, following the methodology described by the World Health Organization for mouse inoculation test, ${ }^{1}$ with some modifications. Breastfed litters were intracranially inoculated with $0.03 \mathrm{ml}$ of a $20 \%$ suspension $(\mathrm{w} / \mathrm{v})$ of RV sample macerate in phosphate buffer solution. The inoculated breastfed animals were left with their mothers and were observed for 21 days. Each inoculated litter remained in isolation conditions.

Those who showed signs of rabies (paralysis, emaciation, hirsute hair, etc.) were humanitarianly slaughtered, with the brain and salivary glands being collected for diagnosis and subsequent characterization of the virus. Once all breastfed litters had been slaughtered, the mothers of each litter were preserved and were kept under observation for 60 days, after which they were slaughtered.

The rabies diagnosis in the animals was carried out through the fluorescence antibody test (FAT) in brain smears, using a monoclonal antibody targeting the RV nucleoprotein, following the standard methodology described by the World Health Organization. ${ }^{2}$

To verify if the antigenic variant with which the females were infected was the same one that was inoculated in their litters, indirect immunofluorescence tests were carried out using a panel of eight monoclonal antibodies (mAbs) standardized by the Center for Disease Control and Prevention of Atlanta, Georgia, USA, in order to identify the most important rabies virus variants circulating in Latin America and the $\mathrm{Ca}$ ribbean, following the methodology described by Díaz et al. $^{3}$

In addition, viral RNA detection was performed in the brains of the breastfed mice and their mothers, as well as from the breastfed animals' salivary glands. Reverse transcription was carried out using total RNA and the corresponding oligonucleotide, using the Superscript $^{\circledR}$ enzyme (Invitrogen). Primers specifically designed to amplify the nucleoprotein gene were used: Jw12* Forward 5' ATGTAACACCYCTACAATG 3' 55- 73 and Jw6 * Reverse 5' CARTTVGCRCACATYTTRTG 3 660-641. The PCR amplification products were purified from an agarose gel with the QIAquick Gel Extraction ${ }^{\circledR}$ kit (Qiagen), following the manufacturer's instructions. The purified products were prepared to be sequenced at $25-100 \mathrm{fmol}$ of polymerase chain reaction product and $3.2 \mathrm{pmol}$ of the corresponding oligonucleotides of each gene.

The eluted product was sequenced in the Beckman Coulter Sequencing Ceq 8800 Genetic Analysis System $^{\circledast}$ (Beckman Coulter).

The sequences were assembled by concatenation and both the direct and the reverse sequence were verified in duplicate using the $C E Q$ program included in the sequencer equipment. The edition of sequences, alignments and nucleotide translation of sequences were carried out with the BioEdit 5.0.9 program. ${ }^{4}$ The sequences were subjected to a BLAST analysis (http://www.ncbi.nlm.nih.gov/Education/BLASTinfo/ credits.html). Multiple alignments were performed in the Clustal W program. ${ }^{5}$

Lactating females that remained healthy at 60 days post-inoculation (p.i.) of the litters were bled from the tail marginal vein to detect anti-RV seroconversion using the rapid fluorescent focus inhibition technique recommended by the World Health Organization. ${ }^{6}$

\section{Results}

\section{Diagnosis and virus characterization}

In all litters inoculated with the different RV samples there were breastfed animals with signs of rabies; only in four of the 27 inoculated samples did breastfed animals survive (Table 1). All breastfed animals that showed positive signs of rabies were positive by FAT and by RT-PCR. In addition, RV was detected by RT$P C R$ in the salivary glands of the breastfed mice that transmitted the disease to their mothers.

Using the eight $\mathrm{mAb}$ reduced panel, antigenic variants of dog (V1), hematophagous bat (V3 and V11), Arizona fox (V7) and Baja California Sur skunk (V10) were identified (Table 1).

In total, three $(11 \%)$ of the 27 lactating females that breastfed inoculated litters showed signs of rabies (paralysis, coarse hair, etc.) at 33,37 and 39 days p.i. of the litter. These females were positive by FAT and RTPCR. Rabies incubation period in the litters of the females that showed signs of rabies was 10, 14 and 15 days, in contrast with the 24 remaining lactating females, whose litters incubation period was 6.5 days on average (range, 5-10 days p.i.).

The RV variants detected with the eight-mAb panel in females that acquired the disease was the same shown by the inoculated litters, with two corresponding to variant 11 (vampire) and one to variant 1 (dog). 
Table 1. Results of 60-day observation of the mothers of breastfed BALB/C mice inoculated with different Mexican isolates of rabies virus

\begin{tabular}{|c|c|c|c|c|c|c|c|c|c|}
\hline Species & Place & $\begin{array}{c}\text { Year of } \\
\text { collection }\end{array}$ & $\begin{array}{c}\text { Antigenic } \\
\text { variant in } \\
\text { mice }\end{array}$ & $\begin{array}{c}\text { Number of } \\
\text { breastfed } \\
\text { mice in } \\
\text { the litter }\end{array}$ & $\begin{array}{l}\text { Mortality } \\
\text { from } \\
\text { rabies in } \\
\text { the litter* }\end{array}$ & \begin{tabular}{l|} 
Rabies \\
transmission \\
to the \\
mother
\end{tabular} & Cannibalism** & $\begin{array}{l}\text { Antigenic } \\
\text { variant } \\
\text { in the } \\
\text { mother }\end{array}$ & $\begin{array}{l}\text { Surviving mothers } \\
\text { sero- conversion } \\
(60 \text { days })^{* * *}\end{array}$ \\
\hline Human & Mexico city & 1991 & 1 & 5 & 5 & & & & 0.25 \\
\hline Bovine & Chiapas & 1991 & 3 & 4 & 4 & & & & 0 \\
\hline Bovine & Chiapas & 1994 & 3 & 3 & 2 & & 1 & & 0 \\
\hline Bovine & $\begin{array}{l}\text { State of } \\
\text { Mexico }\end{array}$ & 1994 & 11 & 5 & 5 & & & & 0 \\
\hline Bovine & Puebla & 1994 & 1 & 3 & 3 & & & & 0 \\
\hline Bovine & Veracruz & 1991 & 11 & 9 & 9 & Positive & & 11 & \\
\hline Bovine & Hidalgo & 1995 & 11 & 8 & 8 & & & & 0 \\
\hline Bovine & Morelos & 1994 & 11 & 9 & 9 & Positive & & 11 & \\
\hline Caprine & Michoacán & 1991 & 3 & 2 & 2 & & & & 0 \\
\hline Caprine & Puebla & 1990 & ND & 5 & 4 & & & & 0 \\
\hline Caprine & Tlaxcala & 1991 & 1 & 6 & 6 & & & & 0 \\
\hline Ovine & $\begin{array}{l}\text { State of } \\
\text { Mexico }\end{array}$ & 1994 & 11 & 7 & 7 & & & & 0 \\
\hline Ovine & $\begin{array}{l}\text { State of } \\
\text { Mexico }\end{array}$ & 1994 & 11 & 6 & 6 & & & & 0 \\
\hline Equine & Michoacán & 1991 & 3 & 5 & 4 & & 1 & & 0 \\
\hline Equine & Mexico City & 1994 & 1 & 4 & 4 & & & & 0 \\
\hline Equine & Puebla & 1990 & 3 & 6 & 6 & & & & 0 \\
\hline Porcine & Mexico City & 1994 & 1 & 1 & 1 & & & & 0 \\
\hline Porcine & Mexico City & 1994 & 1 & 9 & 7 & Positive & & 1 & \\
\hline Dog & Durango & 1991 & 1 & 5 & 5 & & & & 0 \\
\hline Dog & Oaxaca & Sin fecha & 1 & 8 & 8 & & & & 0 \\
\hline Dog & Puebla & Sin fecha & 1 & 4 & 4 & & & & 0 \\
\hline Cat & Michoacán & 1991 & 1 & 4 & 4 & & & & 0 \\
\hline Cat & Jalisco & 1990 & ND & 6 & 4 & & 1 & & 0.28 \\
\hline Cat & Tlaxcala & 1990 & 1 & 6 & 6 & & & & 0 \\
\hline Wildcat & Chihuahua & & 7 & 6 & 6 & & & & 0 \\
\hline Wildcat & Sonora & 1990 & 7 & 1 & 1 & & & & 1.39 \\
\hline Skunk & BCS & 1991 & 10 & 4 & 4 & & & & 0 \\
\hline
\end{tabular}

The three RVs that were transmitted from breastfed litters to their mothers came from non-reservoir species (two bovines and one pig). The sequencing analysis of a fragment of the nucleoprotein gene revealed that both bovine isolates corresponded to viruses of vampire origin and the porcine one was of canine origin. These results were consistent with their antigenic characterization. The bioinformatics analysis corroborated that the lactating females had the same virus as their litters (100\% similarity). 


\section{Test for anti-RV neutralizing antibodies}

Among the 24 lactating females that remained healthy at day 60 p.i. of their litters, three (12.5\%) showed the presence of anti-RV antibodies with titers of $0.25,0.28$ and $1.31 \mathrm{IU}$ (Table 1). Due to the physical conditions of the sick females and sick breastfed litters, obtaining blood from these animals was not possible.

\section{Discussion}

Using a murine model, this work demonstrated the possibility of rabies vertical transmission from breastfed litters to their mothers, since three of the $27 \mathrm{fe}$ males that breastfed their RV-infected litters acquired the disease, and the analyses showed that they had the same virus as their respective litter. It is probable that RV inoculation from breastfed litters to females occurred through lacerations caused during breastfeeding, since neonate mice have small and sharp teeth. RV was detected by RT-PCR in the salivary glands of the breastfed mice that transmitted the disease to the females.

A common denominator in all three cases was that the litters were numerous (nine individuals); therefore, we assume that this condition increases the probabilities of infection of the female due to higher contact, together with the fact that all three cases had long incubation periods of the disease (10 to 15 days). According to our results, litter size appeared to be more important than cannibalism, since in some lactating females cannibalism was observed and no one contracted the disease (Table 1).

Signs of rabies in infected mothers appeared after the 21 observation days recommended for the MIT, which explains why the phenomenon had not been reported. ${ }^{1}$

Three of the 24 lactating females that were healthy at 60 days p.i. of the litters showed anti-RV seroconversion (Table 1), which demonstrates that mothers were being subjected to stimuli with the RV by their infected litters. Several articles show high prevalence of anti-RV antibodies with very low or no presence of the virus, particularly in Chiroptera, hyenas, foxes and also in the human being. ${ }^{7-9}$ This may be due to exposure to sub-lethal doses of RV.

Vertical transmission of rabies in the mother-son direction has been described as being highly unlikely, since the virus is limited to nerve tissue and does not circulate in the blood. In human cases, Aguèmon et al.., ${ }^{10}$

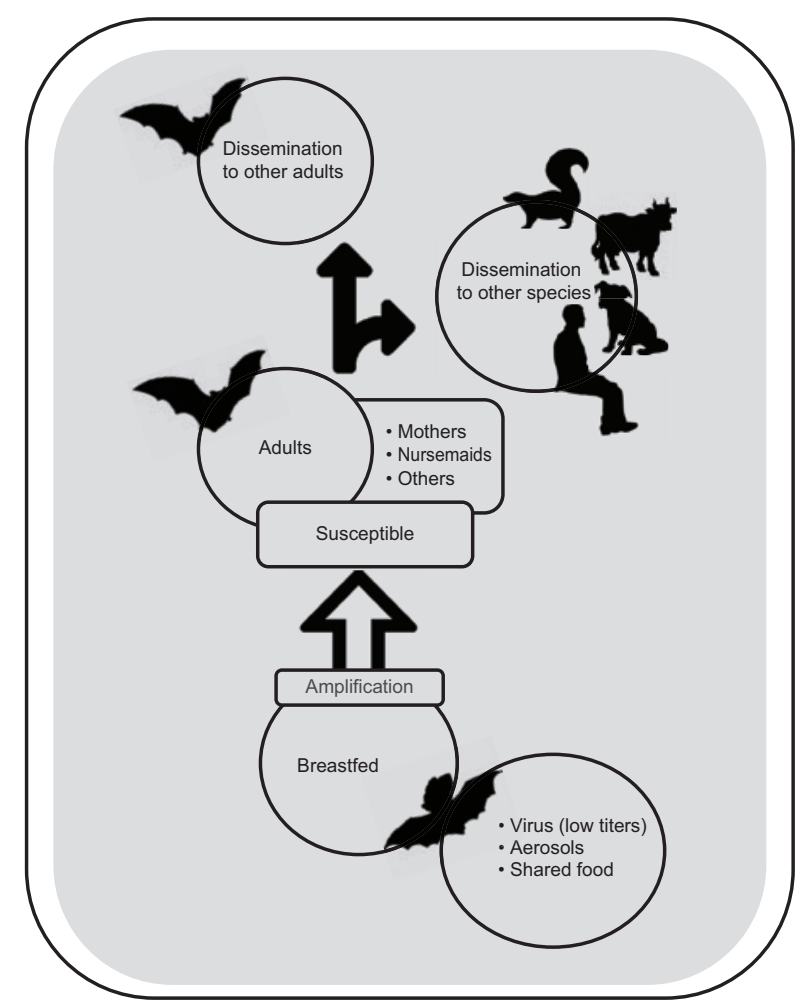

Figure 1. Litter-to-mother vertical transmission hypothesis. This model proposes that the rabies virus might be preserved in the wild by transmission from neonates (susceptible to contracting rabies, e.g., via aerosols, and they would act as amplifiers of the virus) to females, also susceptible during breastfeeding.

in 2016, described healthy babies that were born to mothers with rabies that succumbed to the disease.

Neonates might act as RV amplifiers; sub-lethal doses for adults have been observed to be able to affect infants given their high susceptibility, in addition to the fact that attenuated vaccine strains, which are harmless to adults, can make infants sick. ${ }^{11}$ Thus, we might establish a hypothetical mechanism of RV preservation in a reservoir population, where neonates would amplify low doses of the virus and could disseminate it with greater success among susceptible congeners, in a process depicted in Figure 1. Supporting this hypothesis is the fact that, in Chiroptera, the prevalence of antibodies against Lyssavirus coincides with the mating season. ${ }^{12}$ In addition, Streicker et al. ${ }^{13}$ concluded in 2012 that the elimination of adult hematophagous bats using anticoagulants increased the dissemination of RV, by selecting a population of susceptible young animals that efficaciously amplify the RV.

It is also necessary to consider that, in species that have the ability to hibernate, the hibernation period would maintain the RV latent due to a decreased metabolic activity, with the virus being reactivated when 
animals resume their activity. ${ }^{12}$ Another important factor in transmission of the virus is the presence of maternal antibodies and their duration, ${ }^{14}$ which in Chiroptera appears to be short..$^{15}$ Observations in hematophagous bats demonstrated that the litters of these animals are breastfed for long periods (between seven and nine months); ${ }^{16}$ this may be important in the transmission of the virus, since close contact is prolonged.

Some Chiroptera rabies isolates have been described to be able to be virulent by epithelial inoculation in a higher proportion than by intramuscular route..$^{17}$ In this work, two of the viruses that caused female death came from Chiroptera. These variants might be able to infect epithelia. In addition, Lyssaviruses can penetrate the central nervous system via the skin through sensory nerves. ${ }^{18}$

The phenomenon herein described may occur in nature and favor the perpetuation and establishment of enzootic infections in Lyssavirus wild reservoirs

\section{References}

1. Koprowski H. The mouse inoculation test. En: Meslin FX, Kaplan MM Koproaski $\mathrm{H}$, editores. Laboratory techniques in rabies. Suiza: World Health Organization; 1996.

2. Dean DJ, Abelseth MK, Atanasiu P. The fluorescent antibody test. En: Meslin FX, Kaplan MM, Koproaski H, editores. Laboratory techniques in rabies. Suiza: World Health Organization; 1996.

3. Díaz AM, Papo S, Rodríguez A, Smith JS. Antigenic analysis of rabies virus isolated from Latin America and the Caribbean. Zentralbl Veterinaer B. $1994 ; 41: 153-160$.
4. Hall TA. BioEdit: a user-friendly biological sequence alignment editor and analysis program for Windows 95/98/NT. Nucleic Acids Symp Ser. 1999;41:95-98.

5. Thompson JD, Higgins DG, Gibson TJ. CLUSTAL W: improving the sensitivity of progressive multiple sequence alignment through sequence weighting, position-specific gap penalties and weight matrix choice. Nucleic Acids Res. 1994;22:4673-80.

6. Smith JS, Yager PA, Baer GM. A rapid reproducible test for determining rabies neutralizing antibody. Bull World Health Organ. 1973;48:535-541.

7. Belcher DW, Wurapa FK, Atuora DOC. Endemic rabies in Ghana. American J Am J Trop Med Hyg. 1976;25:724-729.

8. Malaga H, López-Nieto E, Gambirazio C. Canine rabies seasonality. Int J Epidemiol. 1979;8:243-245.

9. Ogunkoya AB, Beran GW, Umoh JU, Gomwalk NE, Abdulkadir IA. Serological evidence of infection of dogs and man in Nigeria by lyssaviruses (family Rhabdoviridae). Trans R Soc Trop Med Hyg. 1990; 84:842-845.

10. Aguèmon $C T$, Tarantola $A$, Zoumènou $E$, Goyet $S$, Assouto $P$, Ly $S$, et al. Rabies transmission risks during peripartum -Two cases and a review of the literature. Vaccine. 2016;34:1752.

11. Arai YT. Virulence of chick embryo fibroblast-passaged flury HEP rabies virus and its revertants in mice. Microbiol Immunol. 1985;29:811-823.

12. George DB, Webb CT, Farnsworth ML, O'Shea TJ, Bowen RA, Smith DL, et al. Host and viral ecology determine bat rabies seasonality and maintenance. Proc Natl Acad Sci U S A. 2011;108:10208-10213.

13. Streicker DG, Recuenco S, Valderrama W, Benavides JG, Vargas I, Pacheco V, et al. Ecological and anthropogenic drivers of rabies exposure in vampire bats: implications for transmission and control. Proc Biol Sci. 2012;279;3384-3392.

14. Hayman DT, Luis AD, Restif O, Baker KS, Fooks AR, Leach $C$, et al. Maternal antibody and the maintenance of a lyssavirus in populations of seasonally breeding African bats. PloS One. 2018;13:e0198563.

15. Obregón-Morales C, Aguilar-Setién Á, Perea-Martínez L, Galvez-Romero G, Martínez-Martínez FO, Aréchiga-Ceballos N. Experimental infection of Artibeus intermedius with a vampire bat rabies virus. Comp Immunol Microbiol Infect Dis. 2017;52:43-47.

16. Romero-Almaráz L, Aguilar Setién A, Sánchez-Hernández C. Gestación y nacimientos. En: Murciélagos benéficos y vampiros. Características, importancia, rabia, control y conservación. México: AGT; 2006.

17. Davis AD, Morgan SM, Dupuis M, Poulliott CE, Jarvis JA, Franchini R, et al. Overwintering of rabies virus in silver haired bats (Lasionycteris noctivagans). PLoS One. 2016;19;11(5):e0155542.

18. Begeman L, GeurtsvanKessel C, Finke S, Freuling CM, Koopmans M, Müeller T, et al. Comparative pathogenesis of rabies in bats and carnivores, and implications for spillover to humans. Lancet Infect Dis. 2017; 18:e147-e159. 